\title{
Development of an electrocoagulation equipment for wall paint wastewater treatment
}

INGENIERÍA QUÍMICA

\section{Desarrollo de un equipo de tratamiento de agua residual de pintura de construcción mediante electrocoagulación}

\author{
Gonzalo Alberto Forero-Buitrago ${ }^{1}$, Rocío Hernández-Lara², Omar Rojas ${ }^{2}$ \\ ${ }^{1}$ Escuela Colombiana de Ingeniería Julio Garavito, Centro de Estudios Hidráulicos, Bogotá, \\ Colombia \\ ${ }^{2}$ Servicio Nacional de Aprendizaje SENA, Centro de Gestión Industrial, Grupo de \\ investigación Neurona CGI, Bogotá, Colombia \\ §gonzalo.forero@mail.escuelaing.edu.co,rohernandezlara@misena.edu.co,oyrojas54@misena.edu.co
}

Recibido: 29 de octubre 2019 - Aceptado: 15 de abril de 2020

\begin{abstract}
This article describes the tests carried out to evaluate the process efficiency water treatment by electrocoagulation in construction paint wastewater. Electrocoagulation process consists of an electrolytic reactor, equipped with a current source and electrodes responsible for providing the destabilizing ions of colloidal particles, so that they replace the function of the chemical compounds used in conventional wastewater treatment. For the experimental design, we use drinking water and wall paint, in order to treat the solution by electrocoagulation in a treatment scale plant to compare the results before and after treatment, the variables to be measured are: dissolved oxygen (DO); turbidity; $\mathrm{pH}$; conductivity; temperature; chemical oxygen demand (COD).After review the efficiencies obtained, we proceed to the development of an equipment treatment that can treat the wastewater from washing brushes and rollers to be reused again in the washing, avoiding contamination caused by washing tools after painting surfaces in construction processes.
\end{abstract}

Keywords: Electrocoagulation, Electrolysis, Industrial Wastewater Treatment.

\section{Resumen}

El presente artículo, describe los ensayos realizados para evaluar la eficiencia del proceso de tratamiento de agua mediante electrocoagulación en agua residual de pintura de construcción. El proceso de electrocoagulación consiste en un reactor electrolítico, dotado de una fuente de corriente y electrodos encargados de aportar los iones desestabilizadores de partículas coloidales, de manera que reemplazan la función de los compuestos químicos que se 
utilizan en el tratamiento convencional de agua residual. Para el diseño experimental, se utiliza agua potable y pintura de pared, con el fin de someter la solución a tratamiento de electrocoagulación en una planta de tratamiento a escala, con la finalidad de hacer la comparación de los resultados antes y después del tratamiento, las variables medidas fueron: oxígeno disuelto (OD); turbidez; $\mathrm{pH}$; conductividad; temperatura; demanda química de oxígeno (DQO). Después de revisar las eficiencias obtenidas, se procedió a la elaboración de un equipo de tratamiento que permita tratar el agua de lavado de brochas y rodillos para reutilizarse nuevamente en el lavado y evitar de esta manera la contaminación ocasionada por el lavado de brochas y rodillos al pintar superficies en los procesos de construcción.

Palabras clave: Electrocoagulación, Electrolisis, Tratamiento de agua industrial.

\section{Introduction}

Electrocoagulation (EC) is a treatment technology that has begun to take hold in recent decades, although its development took place at the beginning of the last century and was patented in the United States in $1909^{(1)}$. In its simplest form, an electrocoagulation reactor is an electrolytic cell consisting of an anode and a cathode ${ }^{(2)}$ where the electrodes are connected to an external power source. The anode material will be electrochemically corroded by oxidation and the cathode will be subject to reduction. However, more efficient arrays have been tested, such as a pair of anodes and a pair of cathodes connected in series or in parallel which decreases the palliation of the electrodes.

In the experimental design carried out in this study, electrocoagulation in a solution of drinking water and water-based wall paint of two different brands was used as a treatment method, the physicochemical parameters of the solution were measured before and after the treatment, and these values were compared to observe the treatment efficiency of the method in order to make decisions regarding the technology to be used in fluid treatment plants using this technology.

By means of a prototype with a capacity of 3,000 $\mathrm{ml}$ which is a plastic container in the shape of a decanter funnel with an outlet valve at the bottom, with a copper sheet and an aluminum mesh in the shape of a cylinder inserted inside it and connected to a 12-volt current source, the aluminum sheet acts as a cathode and the copper sheet acts as an anode to induce electrolysis within the fluid to be treated.

Electrocoagulation (EC) is a technique that allows wastewater efficient treatment by induce an electric current in the fluid, the internal charges are separated into positive and negative ones, travelling to their respective poles ${ }^{(3)}$, thus destabilizing the emulsion in its components, decanting the heavier solids and floating the components that are less dense than water ${ }^{(4)}$, thus allowing the components of industrial wastewater to be separated into their initial components, with the purified water remaining in the container central part. So, the main objective is developing a residual paint water treatment equipment that allows to recirculate the washing water measure the change of the physicochemical parameters of a paint water discharge treated with electrocoagulation.

\section{Methodology}

\subsection{Sample collection}

Two samples of wastewater of different brands and colors were analyzed, the first one in blue and the second one in white color. A volume of $30 \mathrm{ml}$ was taken from each paint and diluted in 2,000 $\mathrm{ml}$ of drinking water, as shown in Table 1. 
The paints used have within their content, titanium dioxide, so it is thought that having this component is more available to have better results for electrical conductivity in the fluid to perform the test of electrocoagulation.

Table 1. Sample quantities of paint and dilutions made for the tests

\begin{tabular}{ccccc}
\hline Sample & $\begin{array}{c}\text { Quantity } \\
\text { ml }\end{array}$ & Brand & $\begin{array}{c}\text { Diluted } \\
\text { in }\end{array}$ & $\begin{array}{c}\text { Quantity } \\
\text { ml }\end{array}$ \\
\hline $\begin{array}{c}\text { Blue } \\
\text { pain }\end{array}$ & 30 & Kolor & $\begin{array}{c}\text { Pure } \\
\text { water }\end{array}$ & 2,000 \\
$\begin{array}{c}\text { White } \\
\text { paint }\end{array}$ & 30 & $\begin{array}{c}\text { Vinilte } \\
\mathrm{x}\end{array}$ & $\begin{array}{c}\text { Pure } \\
\text { water }\end{array}$ & 2,000 \\
\hline
\end{tabular}

Figure 1 presents the preparation process of the solution of paint and water to be electrocoagulated. Liquid paint was measured in a quantity of $30 \mathrm{ml}$ in order to prepare the final solution to be filled with water up to $2,000 \mathrm{ml}$.
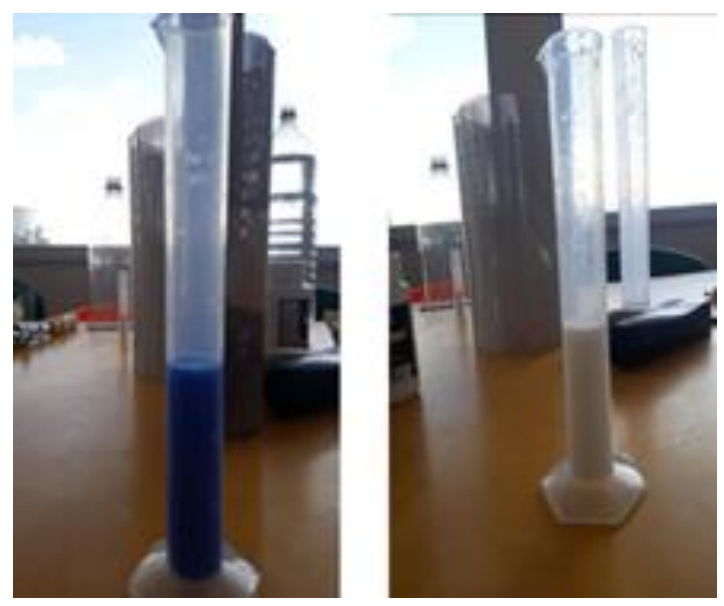

Figure 1. Amount of paint in the samples to perform the electrocoagulation test

A representative $200 \mathrm{ml}$ sample was extracted from the paint water sample which was subjected to electrocoagulation for the analysis of pretreatment parameters, chemical oxygen demand (COD), dissolved oxygen (OD), turbidity, conductivity, $\mathrm{pH}$ and temperature.

On the other hand, Figure 2 presents the electrocoagulation scaled prototype made of recycled materials, using a 5-liter emptied bottle of drinking water. PVC pipes were connected to each other to create a customised base. The prototype is equipped with a twelve-volt voltage converter, with pinch outputs to the cathode and anode to induce current into the sample. For the control of the liquid, a plastic outlet valve was used that can be adapted to the plastic container.

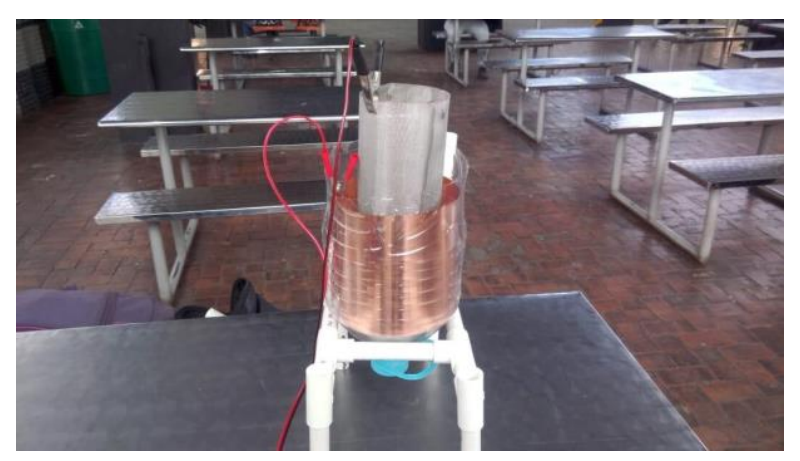

Figure 2. Scale prototype for electrocoagulation water treatment

\subsection{Electrocoagulation process}

In order to explain the electrocoagulation process, dynamic electrolysis process will be explained in detail, which is similar to the electrocoagulation process in wastewater.

Distilled water has a low conductivity, it does not conduct any electric current. If an electric current is to be induced, an acid, for example sulphuric acid, must be added. While the electrolysis process continues, oxygen gas and hydrogen gas are released, the negatively charged hydrogen ions migrate to the positive electrode and the positively charged oxygen ions to the negative electrode. These released gases come from the added acid, because the sulphuric acid is formed by two hydrogen atoms, one sulphur atom and four oxygen atoms, so that the original component has been separated into its main elements thus causing a separation of the emulsion into its basic elements present in the water, in this case the sulphuric acid. 
After being separated by the induction of the electric current, these last ones begin to float to the surface of the water or to decant according to their density with respect to the water that surrounds it, causing that the lightest ones float in the surface and the heaviest ones decant in the bottom of the container, causing that they can be separated easily by physical means after this process.

In the same way, the paint has titanium dioxide, ammonia and acrylic vinyl, where all these compounds have hydrogen and oxygen, by inducing current in the emulsion separates the oxygen gas with positive charge that migrate to the negative electrode and hydrogen gas with negative charge that migrate to the positive electrode, when separated, are then the remnants that are separated by charges and densities, in this case the titanium, nitrogen and carbon present in the compounds of the paint.

In order to carry out the electrocoagulation process, it was necessary to design a scale prototype, consisting of a Polyethylene Terephthalate container in the form of a decanter funnel with an outlet valve, a copper sheet and an aluminum sheet, a 12-volt current converter with an outlet to two connectors marked on their positive and negative poles. The prototype has a capacity of $3,000 \mathrm{ml}$ and the emulsion was left under electric current for one hour.

\subsection{Chemical reactions to be produced during electrocoagulation}

The aluminum ions are mixed with the negatively charged suspended material by decanting it to the bottom of the vessel, while all substances lighter than water, which are susceptible to mixing with the hydrogen, are carried away by the micro-bubbles of the reaction so that a phase separation takes place within the emulsion corresponding to the different densities of the materials that make up the fluid under treatment ${ }^{(5)}$. The reactions that take place in the process are described below:

In Eq. 1, hydrogen gas with negative charge migrate to the positive electrode and to the surface in a reduction process.

$$
\begin{aligned}
& \mathrm{H}^{++2 e} \rightarrow \mathrm{H}_{2} \uparrow \rightarrow \text { reduction } \text { (Eq.1) } \\
& \text { Organic Matter }^{-2 e} \rightarrow \text { reduction }
\end{aligned}
$$

Then in Eq. 2, the aluminum ions travel towards the positive electrode and begin to be mixed with other particles that are present in the emulsion. Once it has reached a considerable weight, it is settled down with the material that has joined, which makes it an efficient removal system.

$$
\begin{gathered}
A l^{0-3 e} \rightarrow A l^{3+} \quad(\text { Eq.2) } \\
A l^{3+} \text { Suspended } \\
\text { Material } \rightarrow A l^{3+} \text { Decanted material }
\end{gathered}
$$

To see the particles behavior or cohesion at a microscopic level the sample was submitted to a visual examination with a $400 \mathrm{X}$ magnification with a Hensoldt Wetzlar equipment in order to observe, obtaining Figure 3, as you can see, in the blue paint you can see the particles, in the white paint due to the color was not clear enough to be able to differentiate what was happening.

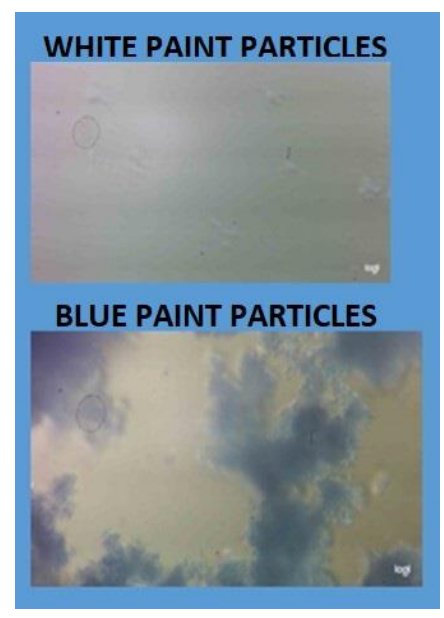

Figure 3. Paint particles at the microscope 
The water and wall paint samples were subjected to electrocoagulation treatment in the prototype for the course of 1 hour, in order to compare the physicochemical parameters before and after the EC treatment, where the separation process takes place. In Figure 4, it is possible to see the particles separated on the right side corresponding to the photographs of the treated sample.

\subsection{Analysis Methods}

The determinations of $\mathrm{pH}$, conductivity, temperature and turbidity were obtained directly through a HI 9828 Hanna multiparameter instrument. Likewise, samples of water solutions with COD paint were made by adding $1 \mathrm{ml}$ of $\mathrm{H}_{2} \mathrm{SO}_{4}$ because the initial $\mathrm{pH}$ was 7.76 and 7.95 .

\section{Results and discussion}

\subsection{Physicochemical analysis of wastewater}

The physicochemical parameters of water samples with paint before electrocoagulation can be seen in Table 2 .
Table 2. Physicochemical parameters of the sample of water with paint without EC treatment

\begin{tabular}{ccc}
\hline 2L total sample & $\begin{array}{c}\text { Blue Paint } \\
\text { sample }\end{array}$ & $\begin{array}{c}\text { White Paint } \\
\text { sample }\end{array}$ \\
\hline Temperature & $19.9^{\circ} \mathrm{C}$ & $20.4^{\circ} \mathrm{C}$ \\
OD & $6.19 \mathrm{mg} / \mathrm{L}$ & 6.16 \\
$\mathrm{pH}$ & 9.11 & 8.01 \\
Turbidity & $13,766 \mathrm{NTU}$ & $78,800 \mathrm{NTU}$ \\
Conductivity & $225 \mu \mathrm{S} / \mathrm{cm}$ & $261 \mu \mathrm{S} / \mathrm{cm}$ \\
& $1,002.53 \mathrm{mg}$ & $8,354.43 \mathrm{mg}$ \\
& $\mathrm{O} 2 / 1$ & $\mathrm{O} 2 / 1$ \\
COD & $3-100 \mathrm{ml}$ & $1-100 \mathrm{ml}$ \\
\hline Dilution & & \\
\hline
\end{tabular}

\subsection{Electrocoagulation treated analysis}

It is very important to highlight a result obtained after carrying out several tests with different samples to be treated, it is the capacity of destabilization of EC, in spite of the fact that it is disconnected from the current, as the sample is destabilized, the longer the rest time of the sample the more effective this separation is, this can be seen in the paint samples in Figures 5 and 6.
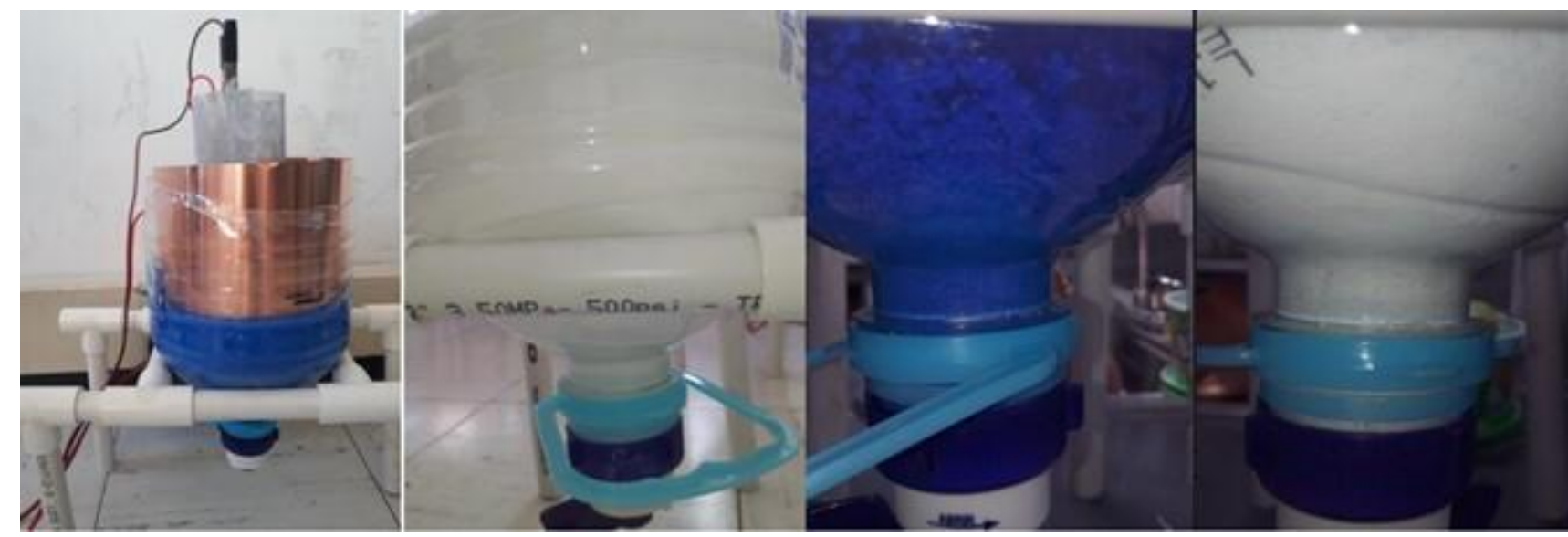

Figure 4. Left: two samples before treatment. Right: two samples after treatment 


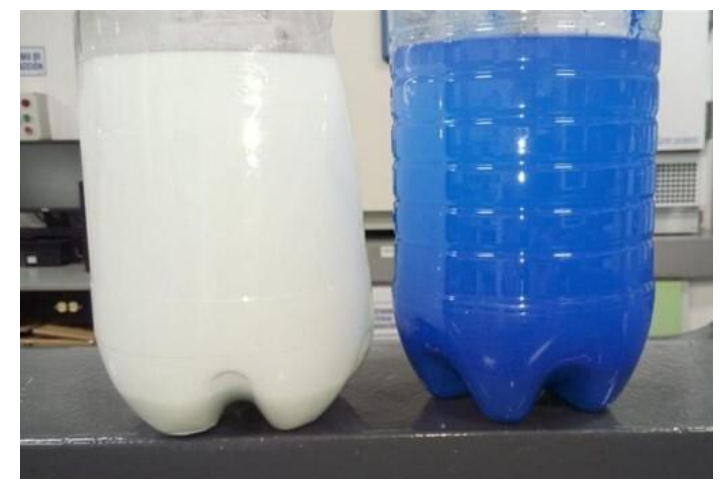

Figure 5. Samples after 1 hour of Electrocoagulation

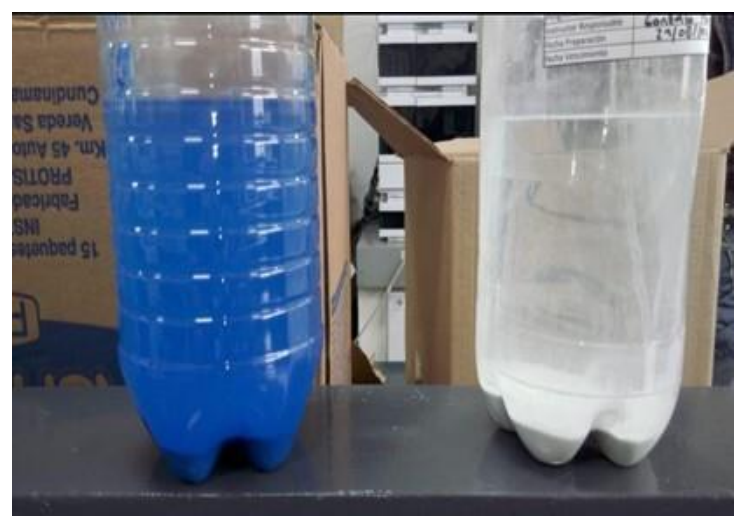

Figure 6. Samples after 1 hour of Electrocoagulation 5 days later

As the white and blue paints have different components, since they are of different brands, it can be seen how the separation was more efficient in the white paint sample.

The results of the measurement of physicochemical parameters of $\mathrm{pH}$, conductivity, temperature, turbidity, DO and COD, before and after the treatment with their efficiency in removal can be seen in Table 3 .

OD: Dissolved oxygen decrease by $3 \mathrm{mg} / \mathrm{liter}$ for the two samples, this is due to the oxygen gasification processes in the electrolysis which in turn allows the processes of separation of the emulsion in the water. It is essential to continue research in electrocoagulation processes with induced aeration, to ensure that the oxygen is not exhausted but continuously supplied to allow the separation process in a more efficient way ${ }^{(6)}$.
pH: Increases due to oxidation-reduction processes ${ }^{(7)}$, however, this change is not significant enough to be considered as negative, since the largest change was $1.67 \mathrm{mg} / \mathrm{l}$.

Turbidity: The changes in turbidity should be highlighted because, as it is a paint, it is one of the most problematic aspects in wastewater. In industries where pigments are used, the most problematic aspect is separating these pigments to avoid seeing colored pigments in their discharges, as is the case in the leather tanning industries ${ }^{(8)}$, an industry in which EC tests have also been carried out with good results, the change in turbidity is from a minimum of $88.6 \%$ to $96.82 \%$ in just 1 hour of treatment.

Conductivity: This is another value to highlight, because the paint contains metals such as titanium dioxide among others, within its internal components. For this reason, it could be expected that when using the aluminum, it can stay in the sample by means of electrolysis, if this is the case, the conductivity would increase. But this is not the case, the Aluminum ions were mixed with the elements separated from the paint by induction of current and decanted being separated from the emulsion ${ }^{(9)}$, in this way, if the conductivity and COD decrease after the treatment, it suggests that it may be possible to remove heavy metals in different problematic industrial mixtures, which may be an excellent subject for further investigation of these procedures.

COD: It was reached from $8 \%$ to $40.5 \%$ in the removal of COD in one hour of treatment, which infer in the capacity of the EC to make a separation of a complex mixture or water emulsion with different components, in its essential components separated by densities ${ }^{(10)}$, allowing the separation in its different products and being able to be used in different industrial sectors. 
Table 3. Physicochemical parameters after one hour of treatment by EC

\begin{tabular}{ccccccc}
\hline Parameters & $\begin{array}{c}\text { Blue sample } \\
\text { after 1 hour } \\
\text { of treatment }\end{array}$ & $\begin{array}{c}\text { White sample } \\
\text { after 1 hour } \\
\text { of treatment }\end{array}$ & $\begin{array}{c}\text { Blue sample } \\
\text { before } \\
\text { treatment }\end{array}$ & $\begin{array}{c}\text { White } \\
\text { sample } \\
\text { before } \\
\text { treatment }\end{array}$ & $\begin{array}{c}\text { Blue } \\
\text { Difference } \\
\text { between } \\
\text { before and } \\
\text { after } \\
\text { treatment }\end{array}$ & $\begin{array}{c}\text { White } \\
\text { Difference } \\
\text { between } \\
\text { before and } \\
\text { after } \\
\text { treatment }\end{array}$ \\
\hline $\begin{array}{c}\text { DO } \\
(\mathrm{mg} / \mathrm{L})\end{array}$ & 3.06 & 3.16 & 6.19 & 6.10 & -3.10 & 3.00 \\
$\mathrm{pH}$ & 9.48 & 9.68 & 9.11 & 8.01 & +0.37 & +1.67 \\
$\begin{array}{c}\text { Turbidity } \\
(\mathrm{NTU})\end{array}$ & 436.5 & 8,950 & 13,766 & 78,800 & $-13,330.16$ & $-69,850$ \\
$\begin{array}{c}\text { Conductivity } \\
(\mu \mathrm{S} / \mathrm{cm})\end{array}$ & 180.4 & 175.4 & 225 & 261 & -44.60 & -85.60 \\
$\begin{array}{c}\mathrm{COD} \\
(\mathrm{mg} \text { O2/L) }\end{array}$ & 926.58 & $4,962.02$ & $1,002.53$ & $8,354.43$ & -75.95 & $-3,392.41$ \\
\hline
\end{tabular}

\subsection{Electrocoagulation equipment development for the reuse of wastewater with wall paint}

With the results obtained, experience has led to the adjustment of the variables necessary for the optimization of wastewater treatment from the paint brushes and rollers washing of painting construction industry. The goal of the equipment is then, to wash the tools, treat the water that comes out of the washing to reuse it in a new wash so that it does not go into the sewer.

The equipment is then built with the metals used in the tests mentioned below, leaving a stainlesssteel support structure, with internal plates for zinc, copper and aluminum for electrocoagulation purposes. The equipment was built and installed at the Centro de Tecnologías para la Construcción y la Madera SENA in Bogotá D.C., because is a teaching center where they teach to the apprentices how to paint, which is why they needed equipment where the apprentices paint, the water is treated, the contaminant is separated into solids and the treated water is recirculated to wash the brushes and rollers again.
The equipment built and installed can be seen in Figure 7, where the turbidity characteristics can be seen before the treatment of the washing water at the SENA Centre. Then in the Figure 8, a sample of water taken after the treatment can be seen, showing the degree of separation of paint and water after the electrocoagulation process.

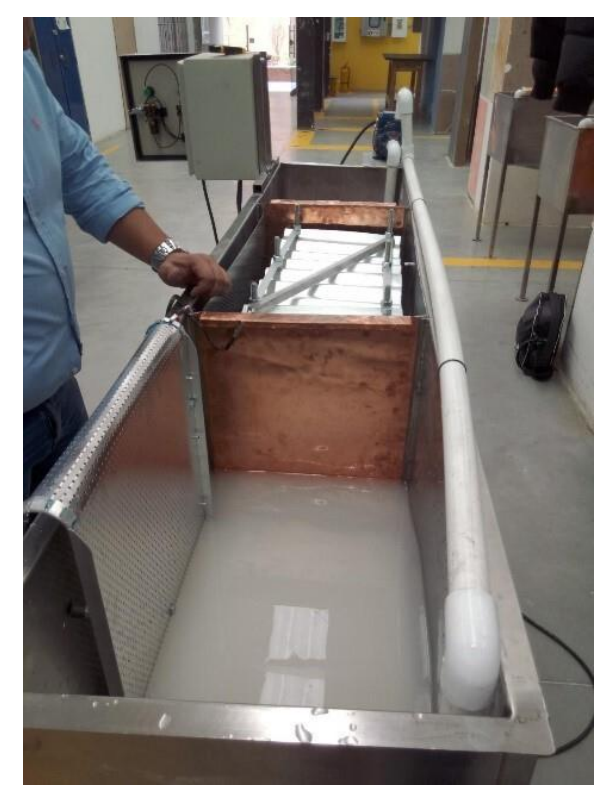

Figure 7. Roller washing water before treatment in the electrocoagulation equipment 


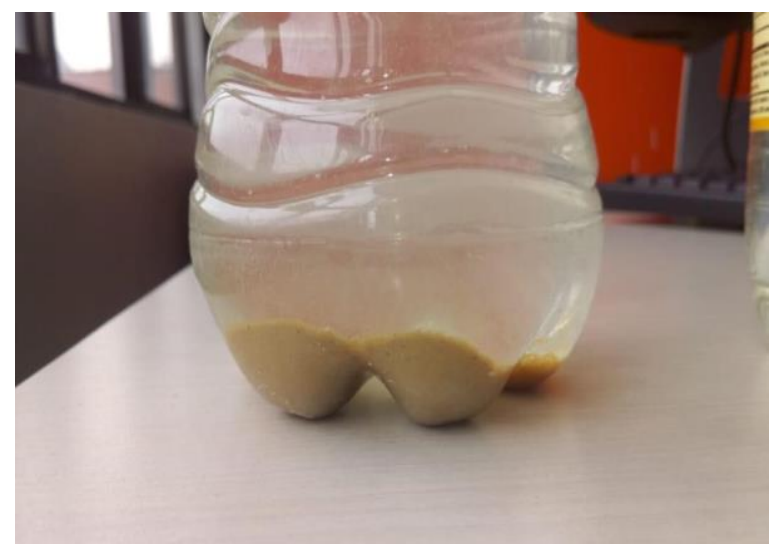

Figure 8. Roller washing water after one hour of treatment in the electrocoagulation equipment and one night of decantation

Finally, Figure 9 shows the detail of the laminar system, where the contact area of the electrically inducing metal for medium solids is increased, while at the same time an accelerated decantation is induced by coalescence, taking advantage of the capacity of the solids to adhere to surfaces, in addition to the electrical current and the inclinations of the sheets that increase the efficiency of the equipment.

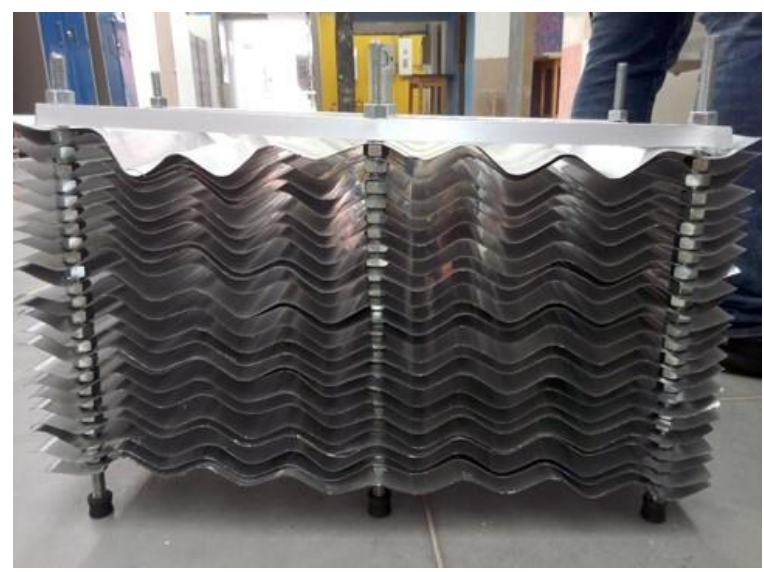

Figure 9. Laminar system for decantation and electrocoagulation of water-based paint removal equipment

The wastewater from the washing brushes and rollers wastewater is perfectly clarified, allowing the recirculation of the water from the washing of rollers and removing the residual paint from the decanters as a solid, as can be seen in the sample before and after passing through the paint treatment equipment. Therefore, it is concluded that EC is an exceptional technology for handling dyes in the construction industry, the equipment is still under study of physicochemical parameters for this reason the results of the treatment in the equipment were not presented.

\section{Conclusions}

Any industrial pollutant that can induce an electrical charge in the water can be separated into its essential elements by Electrocoagulation, so that the separated elements with a positive charge migrate to the negative electrode and elements with a negative charge migrate to the positive electrode, leaving the emulsion ready to be physically separated by three main routes, which are:

- Separation after it adheres to the cathode or anode plate.

- Floating on the water surface.

- Decant; by following these routes, you can be separated by physical means.

Further research into electrocoagulation processes with induced aeration is essential to ensure that oxygen is not exhausted but continuously supplied to enable the separation process to be carried out more efficiently.

It is necessary to investigate and test this technology on industrial waste of all types to achieve the separation and reuse of recoverable industrial elements, since by separating them by means of the electrocoagulation process, they can be returned to the production lines if it is possible to carry out the study and thus have a saving in production costs while reducing pollution. 
This practice allows to give an alternative for the treatment of the wastewater replacing the conventional treatment based on chemicals, the process of Electrocoagulation should be compared with the conventional process with physicochemical measurements. From the experience gained, it is possible to minimize water treatment costs using this technology, it is even possible to adapt conventional treatment plants to operate with electrocoagulation at a viable cost.

It is necessary to encourage and finance treatment trials with Electrocoagulation for other types of discharges, since satisfactory results were obtained with other processes such as seawater desalination, removal of surfactants in water, removal of hydrocarbon oils in water, removal of fats and organic oils in water, among others.

The destabilization of particles by laminar systems, together with electricity, makes the processes more efficient, being of particular importance the contact area of metal and water, so it is one of the most important variables to take into account for the equipment's design.

It is necessary to do research tests measuring the efficiencies with coalescent systems of microscopic size of metals suitable to the fluid to be treated, in order to evaluate the efficiency for different industrial discharges, so that to have a wide range of tests to be able to make equipment to measure the contaminant. If the companies have such equipment, the elements that can be reused in the process are efficiently separated in an economic way for the industrial sector, the raw material can be reused, the amount of pollutant to be disposed of is reduced and the effluent to natural bodies or municipal treatment plants is improved, thus gaining all the interested parties.

\section{References}

(1) Aguilar E. Efficiency's evaluation of an electrocoagulation cell at scale laboratory for water treatment. Rev. del Instituto de Investigación (RIIGEO) FIGMMGUNMS. 2015; 18(35): 69-73. Doi: 10.15381/iigeo.v18i35.11843.

(2) Ruiz AA. La electrocoagulación: una alternativa para el tratamiento de aguas residuales. Revista Lasallista de investigación. 2005; 2(1): 49-56.

(3) Niño GEA, Barrera CAC, García AB, Lumbaque EC. Electrocoagulation as an efficient treatment for the removal of heavy metals from wastewater. Revista Facultad de Ciencias Básicas. 2013; 9(2): 306-317.

(4) Verma SK, Khandegar V, Saroha AK. Removal of chromium from electroplating industry effluent using electrocoagulation. Journal of Hazardous, Toxic, and Radioactive Waste. 2013; 17(2): 146-152. Doi: $\quad$ 10.1061/(ASCE)HZ.21535515.0000170.

(5) Bibiana N, Posada M, Eunice G, Niño A, Posada NBM, Niño GEA. Electrocoagulation system as treatment of galvanic wastewater. Ciencia e ingeniería Neogranadina. 2010; 20(1): 33-44. Doi: 10.18359/rcin.282.

(6) Cañizares P, Martínez F, Sáez C, Rodrigo $\mathrm{M}$. The electrocoagulation, an alternative to the conventional coagulation process of wastewater. Afinidad. 2009; 66(539):2737.

(7) Arias-Cepeda WG. Remoción de Cromo (III) y DQO a través de electrocoagulación en aguas residuales de la industria curtiembre haciendo uso racional de la 
energía [master's thesis]. Bogotá: Universidad Libre de Colombia; 2013.

(8) Diaz JJF, Aguado AEE, Martinez JA. Treatment of wastewater from chemical origin by electrocoagulation. Avances: Investigación en Ingeniería. 2014; 11(1): 65-69. Doi: 10.18041/17944953/avances.1.332.

(9) Vaca MCG, Ubaque CAG, Solórzano JSP. Exploratory study of dye wastewater treatment through the electrocoagulation/electroflotation method. Tecnura. 2016; 20(47): 107-117. Doi:

10.14483/udistrital.jour.tecnura.2016.1.a0 9.

(10) Mendoza AG, Guamán M, Pacheco CA. (2016). Aplicación del principio de electrocoagulación en el tratamiento del agua residual textil. DELOS: Desarrollo Local Sostenible. 2016; 9(26): 10. 